\title{
CHANGING INSTITUTIONAL FRAMEWORK FOR SPATIAL PLANNING IN THE WESTERN BALKAN REGION. EVIDENCES FROM ALBANIA, BOSNIA HERZEGOVINA AND CROATIA
}

\author{
Giancarlo Cotella, Erblin Berisha \\ Interuniversity Department of Regional and Urban Studies and Planning \\ Politecnico di Torino \\ 39 Viale Mattioli, Torino: Italy \\ giancarlo.cotella@polito.it, erblin.berisha@polito.it
}

\begin{abstract}
The contribution aims at providing a preliminary insight on the evolution of the institutional framework for spatial planning in the Western Balkan Region since 1989. It does so by proposing a conceptualization of spatial planning domestic contexts as dynamic objects subject to continuous change, and by identifying the main driving forces that contribute to shaping their patterns of change in the geographical area at stake: (i) domestic transition from a centrally planned economic model to a decentralized model based on free market rules, (ii) process of European integration and the Europeanization mechanisms triggered by the latter. On this basis, the authors explore the territorial administration reforms and evolution of spatial planning legislation specific for Albania, Bosnia Herzegovina and Croatia in the last 25 years in more detail manner, highlighting and discussing both similarities and differences.
\end{abstract}

Keywords: spatial planning systems, comparative planning studies, Western Balkan Region, transition, European integration, path-dependency.

\section{Introduction}

The evolution of spatial planning in the European Union (EU) Member States is a widely investigated topic (Reimer et al. 2014). However, the Western Balkan Region ${ }^{1}$ has been relegated, until now, at the margins of the academic debate. This clearly constitutes a gap, especially in relation to the process of the European integration that is involving the area and is the main reason behind the undertaking of the present research work. Aiming at providing a meaningful contribution to the debate, the article analyzes the evolution of the institutional framework for spatial planning in three countries

\footnotetext{
1 For the purpose of this research, the Western Balkan region is considered to be composed by: Albania, Bosnia Herzegovina, Croatia, Serbia, Republic of Montenegro, FYROM (Former Yugoslavian Republic Of Macedonia) and Kosovo. Similar geographical definitions were adopted in their studies by the World Bank and the European Commission.
} 
of the Western Balkan area that reached different stages in their process of joining the EU - Croatia, Albania and Bosnia Herzegovina ${ }^{2}$ - in order to unravel the complexity of their patterns of change. In order to do so, multiple factors of influence are taken into consideration. Indeed, the evolution of spatial planning institutional framework has been affected by exogenous influences (generating from the EU, the various international organization, international market actors etc.) that in turn had a differential impact in the three contexts depending on the specific domestic conditions (local planning culture, administrative culture, level of socio-economic development, etc.).

The first part of the contribution focuses on the definition of spatial planning systems and proposes a critical review of the methodologies upon which the most known comparative analysis on the matter are based. Then, the authors introduce the main lenses through which the evolution of territorial governance in the Western Balkan Region will be interpreted. They present the main features and implications of the process of transition towards a market economic model, influence of the main international actors as well as the implications of heritage of the communist period. Similarly, they reflect upon the EU integration process and the mechanisms of Europeanization triggered by the latter through the provision of strategic orientation, formal acts and monetary incentive systems. The third and fourth parts of the paper constitute the core of the analysis, describing as they carry out both the reform of the administrative structure for territorial governance in the countries at stake as well as evolution of their spatial planning legislation. A conclusive section rounds off the contribution, summarizing the results of the analysis and highlighting the need for further research on the matter.

\section{Institutionalist approach to spatial planning domestic change}

A spatial planning system may be defined as the institutional framework ${ }^{3}$ allowing for (and regulating), in a specific country, the multiple and complex processes of vertical (between policy levels) and horizontal (between policy sectors and between public and private subjects) interactions addressing the spatial organization of social life. These 'spatial planning activities and processes' occur within the frameworks of legally established objectives, tools, and procedures which, in modern states, are usually derived from fundamental constitutional rights (Janin Rivolin 2012). According to the literature, however, spatial planning systems are not static objects, but change profoundly in time. They are indeed dynamic institutional arrangements subject to continuous patterns of change (ESPON 2007; Stead \& Cotella 2011; Janin Rivolin 2012; Reimer et al. 2014; Cotella \& Janin Rivolin 2015).

Since the beginning of the 1990 s onwards, various studies were developed to understand and compare the evolution of spatial planning in Europe (among others: Newman \& Thornley 1996; CEC 1997; ESPON 2007; Stead \& Cotella 2011; Reimer et al. 2014). Comparative spatial planning

\footnotetext{
2 In order to allow both for a meaningful comparison as well as for appreciation of the differential role played by the international context in the process, the research focused on three States that, despite presenting similarities, are the potential candidate for EU membership, EU candidate country andcurrent EU member State, respectively: Bosnia Herzegovina, Albania and Croatia.

3 Following Moroni (2010:77; see also North 1990), we intend to define institutions as 'sets of basic rules of conduct, acknowledged by a community', which can 'ensure a pattern-coordination among individual actions' and become 'a fund of knowledge accrued over the centuries, and available to all'. Whereas organizations occur 'by deliberate decision', institutions occur 'by convention' as 'the unintentional result of the interplay among intentional decisions and actions' (Moroni 2010:282-283). In particular, the social rule concerning the rights to land ownership is an institution derived from 'conventions' that, along the course of history, have conferred to public authorities the task of assigning rights to land use or, in other words, of deciding 'whether they are more or less absolute or limited by specific conditions and rules' (Larsson 2006:2).
} 
research was initiated by the work of Davies et al. (1989), that analyzed the 'families of law and government structure' of various European states and was then used as a background for the definition of Newman \& Thornley (1996) "families of law" (Nordic, British, Germanic, Napoleonic, East European), upon which a preliminary comparison of the European spatial planning systems is established. During the second half of the 1990s, the EU Compendium of Spatial Planning Systems and Policies (CEC, 1997) proposed a more complex and sophisticated methodology, introducing four so-called 'ideal types' of spatial planning - (i) regional economic, (ii) comprehensive integrated, (iii) land use management and (iv) urbanism - on the basis of a series of variables individuated ad hoc.

However, as Getimis (2012) stresses, the comparative methods adopted in many of those studies present several differences and limitations. As a matter of fact, the increasing diversities between territories, even in the same country, can hardly be interpreted through formal legal and administrative classifications, and similar limitations applies to the static ideal-types formulated in the EU Compendium (see: Stead \& Nadin 2009). Indeed, if we consider the spatial planning system(s) as institutional phenomena resulting from the sum of social, cultural, policy and economic behaviors that characterize a specific context, taking into account only the 'law and government structure' is not enough, as it would not allow for the production of relevant insight in the spheres of planning culture, discourse and practices (Nadin \& Stead 2008; Rivolin 2012). Following this argument Getimis (2012) argues for the need to analyse spatial planning systems 'in motion', in order to fully grasp the flavour and to understand the causes (and the consequences) of the patterns of change that characterize each context.

To add further complexity to the issues at stake, it is worth to mention that the context under scrutiny in this research presents several specific conditions. As a matter of fact, Croatia, Albania and Bosnia Herzegovina belong to the Western Balkan area and, until the edge of the 1990s, were positioned on the Eastern side of the Iron Curtain, hence belonging, in different extents, to the Soviet area of influence. After the collapse of the Soviet bloc, the various satellite states started their transition towards a market oriented economic model almost simultaneously. However, their transformation patterns present relevant distinctions, generating by a multitude of endogenous and exogenous features: internal socioeconomic and cultural features of each context, beginning of the Yugoslavian War, interest of the International Monetary institution (e.g.: the World Bank and the International Monetary Fund - WB and IMF), pace of the European Union Integration process, etc. As one could imagine, this specific conditions had crucial implications for the evolution of the spatial planning systems of each of these countries. Also due to this reason and to the fluidity that these systems maintained until the present days, they have not yet been the object of any comparative analysis or typological classification.

In the light of the above considerations, the proposed analysis of the evolution of the spatial planning systems in the countries at stake build on three intertwined assumptions: (i) the transition process in the Balkan area (hence in the selected countries) has been affected by various international actors (among which IMF, WB, EU etc.); (ii) the influence of these actors is mediated by endogenous factors and path-dependency logics and (iii) the spatial planning systems' patterns of change are the result of interaction between domestic conditions and external influence. Building on these assumptions, for each of the three countries chosen for the analysis, the following sections explore the patterns of change addressing spatial planning since the beginning of the 1990s, when they started their transition towards western-inspired market economic models and their road toward the EU accession. 


\section{Main drivers of change}

In 1989, after the collapse of the communist ideology, the European socialist countries opted for embracing the logics of free market and democracy. The opportunity to "return into Europe" was considered a unique perspective and, in turn, became the main political priority. Pursuing the required transition and transformation process (Tsenkova \& Nedovic-Budic 2006; Adams et al. 2011) presented a wide range of challenges and required the implementation of a number of complex systemic changes. These changes were mainly related with various dimensions: (i) polity dimension, i.e. shift from a single party towards a multiple parties system; (ii) institutional dimension, i.e. decentralization of power; (iii) economic dimension, where economic power is transferred from the old vertical administrative hierarchies towards the private sector and civil society and; (iv) power dimension, i.e. change of dominant interest groups, entrance of new external actors and local actors in the game (new local elites emerging).

Among the actors that had an influence over the transition process in the post-socialist European countries, those exerting the highest influence during the definition of regional and spatial policies may be divided into four categories: global institutions (United Nations, IMF, WB and NATO); supranational institutions (EU), non-governmental organizations (NGOs) and governmental agencies. It has to be pointed out that the role and influence of the international actors has been far from homogeneous (Georgiadis 2008). In general terms, one could argue that this was the consequence of the main features of each domestic context. This appears evident, when one analyses the role of NGOs in Croatia that created a system partially overlapping with local institutions, thus instituting a set of clientelistic and technocratic relations (Tendler 2000). When it comes to the case of Albania, the external actors affected the national context with cooperation initiatives focusing on spatial planning experiences that exerted a strong influence in terms of both economic and political conditionality. In Bosnia and Herzegovina the international actors were directly involved in the definition of the polity structure of the State, within so-called Dayton agreement ${ }^{4}$ that re-established the principles of private property and defined the features of the compensation process and of liberalization policy, which in turn jointly produced spill-over effects over spatial planning.

Table 1. Variables influencing the transition process in the countries under analysis

\begin{tabular}{|l|c|c|c|}
\hline & Croatia & Albania & Bosnia \\
\hline Pre-communist tradition & Industrial societies & Traditional societies & Traditional societies \\
\hline $\begin{array}{l}\text { Type of communist } \\
\text { Regime }\end{array}$ & $\begin{array}{c}\text { Cult of personality/ } \\
\text { bureaucratic-authoritarian }\end{array}$ & Cult of personality & $\begin{array}{c}\text { Cult of personality/ } \\
\text { bureaucratic-authoritarian }\end{array}$ \\
\hline $\begin{array}{l}\text { Mode to communist } \\
\text { collapse }\end{array}$ & Violent & Peaceful & Violent \\
\hline $\begin{array}{l}\text { Post-communist political } \\
\text { system }\end{array}$ & $\begin{array}{c}\text { Semi-democratic system } \\
\text { after the collapse of } \\
\text { former Yugoslavia }\end{array}$ & Semi-democratic system & $\begin{array}{c}\text { Political instability after } \\
\text { the collapse of former } \\
\text { Yugoslavia } \\
\text { (Ethnic violence) }\end{array}$ \\
\hline
\end{tabular}

Source: authors' own elaboration.

4 The Dayton Agreement, also referred to as Paris Protocol by the General Framework Agreement for Peace, was stipulated in 1995 in Ohio (US). It preserved Bosnia as a single state made up of two entities, the Bosniak-Croat federation (Federation of Bosnia Herzegovina) and the Bosnian Serb Republic (Republic of Srbska). 
Various studies show, how the flavor of the transition period in the countries under analysis has been strongly influenced by different variables, as for instance the way that led to communist collapse (Elster et al. 1998), the types of communist regime (Kitschelt et al. 1999) and the pre-communist tradition. These elements contribute to putting into context and interpreting the various national institution, administrative and market reforms that characterized the post-communist reorganization, as they influenced the institutional choices made by the reforming elites in each country, in turn influencing the evolution of territorial governance and spatial planning (Tab. 1).

\section{European integration and Europeanization of spatial planning}

In addition to the legacy of the communist period and the impact of transition, the process of European integration is of particular relevance. As far as the Western Balkan region is concerned, this process has been characterized by very different speeds with Croatia as the only country that achieved the Member State status until date. In this light, it is important to understand the various steps through which the EU enlargement process passes and the way the EU can exert its adjustment pressure through each of them (Fig. 1).

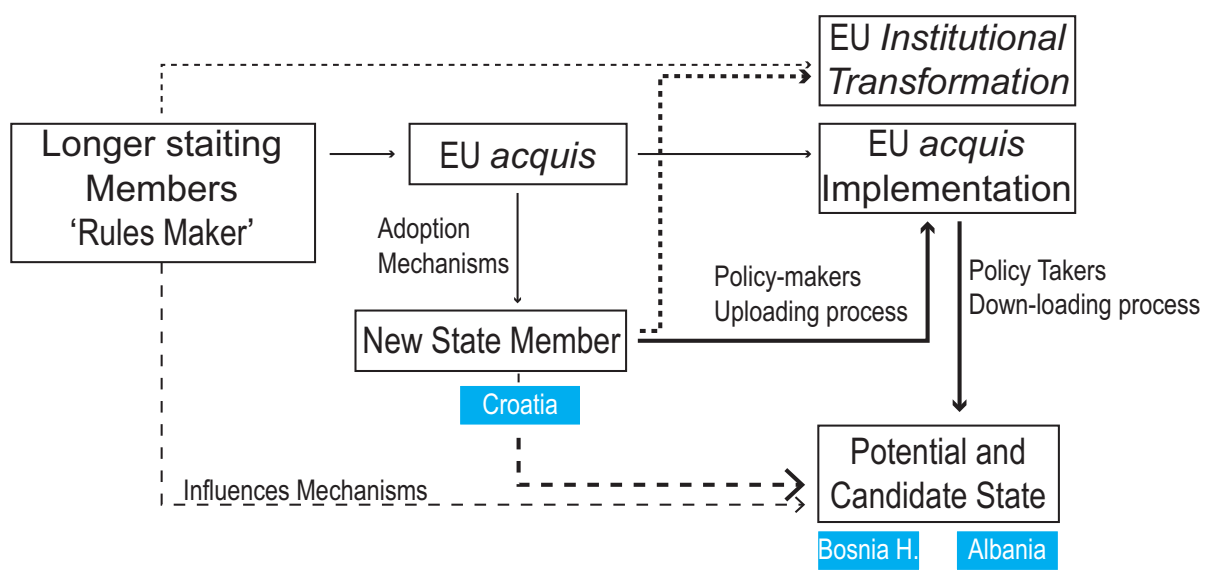

Figure 1. Adjustment pressure and adaptation process

Source: authors' own elaboration on the basis of Sedelmeier, 2006.

While the EU signed Stabilization and Association Process Agreements with the three countries in 1999, the integration process of Albania and Bosnia has been rather slower (Tab. 2). There are many reasons behind Albania's slow fulfillment of the EU accession conditions. Firstly, the political instability from 1990 to 2000 that peaked with the civil war in 1997. Secondly, slow pace and scarce effectiveness of the wider polity, policy, economic and social transformations. Due to this reasons, Albania has granted candidate status only in June 2014, as recognition of its reform efforts and progress made. However, the country still needs to build on and consolidate the reform momentum and focus its efforts on tackling its EU-integration challenges in a sustainable and inclusive way. When it comes to Bosnia Herzegovina, its relation with the EU is further complicated by various misunderstandings related to the political and economic accession criteria. In more details, according to the Progress Report 2015, Bosnia Herzegovina is required to further improve the cooperation and coordination 
between the State level, the Entity levels and the Brčko District Parliament (vertical and horizontal integration). In fact, lack of clarity continues to be visible in the distribution of power between State, Entities, Cantons and Municipalities. For these reasons, among others, Bosnia Herzegovina is still far from the EU accession notwithstanding the entry of Stabilization and Association Agreement (SAA) in June 2015 into force.

Different pace that characterized the three countries under analysis in their path towards the EU affected in turn also the magnitude and quality of their Europeanization. A comprehensive literature has been developed in the last 20 years to understand the relation between the European Integration and Europeanization, with various authors addressing the latter as the main transmission belt of the former (Börzel 2003), in a continual dialectic interaction between the uniformity of the EU and the diversity of the individual Member States (Howell 2002): on the one hand, the European integration process triggers Europeanization mechanisms that generate domestic changes in the countries' governmental, regulatory and discursive structures; on the other hand, Europeanization may be red as the driving force through which the Member States continue to interplay in the European integration process, in so doing influencing the way the EU supranationality evolves.

Table 2. EU Integration in the countries under analysis

\begin{tabular}{|c|c|c|c|c|}
\hline \multirow{4}{*}{ Step } & Instrument & Croatia & Albania & Bosnia \\
\hline \multirow{3}{*}{$\begin{array}{c}\text { Pre- } \\
\text { Adhesion } \\
\text { Agreement }\end{array}$} & Stabilization and Association Process & 1999 & 1999 & 1999 \\
\cline { 2 - 5 } & Stabilization and Association Agreement (SAA) & $2001-2005$ & $2006-2009$ & $2007-2015$ \\
\cline { 2 - 5 } & Potential Candidate & 2004 & 2014 & $\ldots$ \\
\hline Screening & $\begin{array}{c}\text { Program Signed } \\
\text { PHARE, ISPRA, SAPARD, poi IPA }\end{array}$ & $2005-2007$ & 2007 & $\ldots$ \\
\hline Negotiation & Started Screening Step & 2006 & $\ldots$ & $\ldots$ \\
\hline Adhesion & Chapter Discussed Period & $2006-2011$ & $\ldots$ & $\ldots$ \\
\hline
\end{tabular}

Source: authors' own elaboration.

In the light of the above, it is possible to reflect on the various channels through which the EU influences the Member States more or less explicitly in a number of policy fields, including spatial planning. As a matter of fact, despite the absence of regulatory restrictions and requirements, EU has been able to influence the planning practices in the Member States and beyond through the development of concepts and ideas, establishment of EU cohesion policy and implementation of various initiatives with an explicit spatial impact (Böhme \& Waterhout 2008; Adams e al. 2011; Stead \& Cotella 2011; Giannakourou 2012, 2005; Cotella \& Janin Rivolin 2010, 2015). In more detail, it is possible to identify three channels through which the EU's influence over domestic spatial planning systems is delivered - i.e. a dialogic, institutional and instrumental - pivoted around numerous Europeanization catalysts - i.e. strategic orientations, formal acts, economic incentives (Cotella \& Janin Rivolin 2010, 2015).

The dialogical influence operates through the diffusion and dissemination of those concepts and ideas developed within the so-called European spatial planning knowledge arenas (Adams et al. 2011; Cotella et al. 2012) and crystallized in the EU strategic guidelines documents as the European spatial development perspective (ESDP CEC 1999), the EU Territorial agendas (DE Presidency 2007; 
HU Presidency 2011), the Green Paper on territorial cohesion (CEC 2008) and various documents focusing on the Urban dimension of community policies (CEC 1990 1998). The structural influence is exercised through formal acts, i.e. binding instruments, such as directives and regulations (Habitat, Environmental Impact Assessment, Strategic Environmental Assessment etc.), through which the EU imposes specific behaviors hierarchically, leading to legal changes that affect the structure of domestic spatial planning. Lastly, the instrumental influence is a consequence of the various incentive programmes (e.g.: EU cohesion policy, Community Initiatives as INTERREG, URBAN and LEADER) through which the EU exercises an 'economic conditionality' that alters the possibilities of domestic actors through the redistribution of resources and powers (Knill \& Lehmkuhl 1999).

\section{Changing institutional landscape for spatial planning in the Western Balkan region}

\section{Croatia}

With the end of the former Yugoslavia in the early 1990s and subsequent proclamation of the national independence, Croatia started a period of reforms aiming at aligning its administrative system to the new Constitution. In this regard, the 1992 territorial organization act introduced a dual system of local government: a first layer characterized by self-governed municipalities and cities and a second layer of counties hosting both self-government units as well as State representations (Fig. 2). Various authors point out that the process of administrative decentralization has been rather opaque. According to Maleković et al. (2011) the latter was actually accompanied by a process of re-centralization of power implemented at the county level, with State Ministries that put in place a system of central outposts that paralleled the self-government units, continuing to influence the counties' administrative activity. Moreover, while the reduced dimension of the counties allows to respond effectively to local needs, it also prevented consolidation of an articulated system of multilevel governance and, consequently, any attempt to influence the central system bottom-up.

An additional problem consisted in exponential growth of regional imbalances between the northern and southern regions (Maleković \& Puljiz 2009), that led to particular focus on the institution of additional territorial subdivision of the country in NUTS-2 regions in 2007, in order to better answer the needs of the EU pre-accession policy (Fig. 2). Moreover, between 2005 and 2007, various powers and competences were transferred from the counties to the municipal level - and in particular to the Croatian cities - including those concerning spatial planning as institutionalized by the new Law on spatial planning and constructions approved in 2007.

In 2009, the central government introduced also a new framework law for regional development, which provides various indications directly descending from and related to the EU pre-accession and cohesion policy. In the following year a set of bottom-up strategies was drafted in order to achieve higher coordination between local, sub-national and national actors on the basis of the principle of subsidiarity. In addition to this, the adopted Regional Development Strategy 2011-2013 (RDS) identifies a number of guidelines and principles aiming at further devolution of competences based on functional and fiscal decentralization and territorial reorganization. Despite the described reforms, however, the Croatian administrative system is still affected by several problems, including among others the reduced dimension of the counties, limited fiscal 
capacity of local units, lack of a vertical coordination between the central and the sub-national levels and lack of local institutional capacity of sub-national units (Maleković et al. 2011; Maleković \& Puljiz 2009).

21 Counties

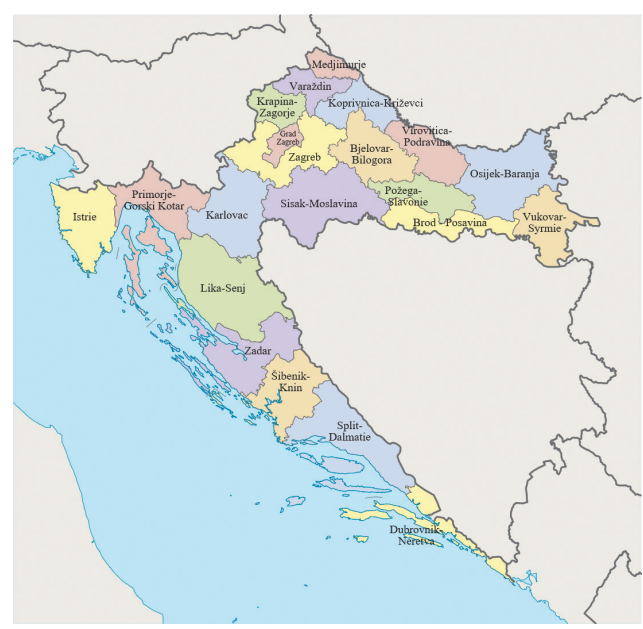

NUTS-2 Regions

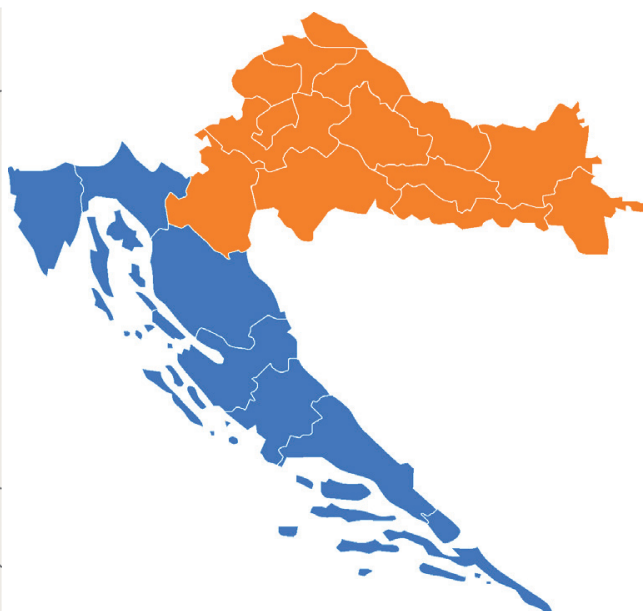

Figure 2. Territorial subdivision of Croatia in Counties and NUTS-2 regions Source: https://commons.wikimedia.org/wiki/File:Counties_of_Croatia-fr.svg.

Spatial planning in Croatia lies under the competences of the Ministry of Environmental Protection, Planning and Construction, and is framed by two main laws. The first law on spatial planning was approved in 1994 (OG 30/94) focusing on the institutions responsible for spatial planning and regional development and paying particular attention to the protection and management of coastline areas. The law and its further amendments provided for a division of responsibilities between different levels of government. As a consequence, in 1997 the country approved the National strategy of spatial development identifyingthe aims of long-term spatial development. In addition, a National spatial development schedule was approved in 1999 determining measures and activities in order to implement the National strategy.

Moreover, the law entitles the counties and the city of Zagreb for the preparation of Physical plans for the counties and the capital city, in order to define the aims of spatial organization, protection, use and management of the environment. It also establishes development of a more general municipal Spatial development plan and detailed Urban development plans for each municipality. The Spatial development plan of the municipality defines the goals and conditions for spatial development, distributes the functions on the territory and identifies the areas to be rebuilt, rehabilitated or protected due to peculiar environmental or cultural value. In addition, the plan identifies the areas for which more detailed urban development plans are to be drafted.

After reaching the status of Member State in 2013, Croatia adopted a new legal framework for spatial planning (Spatial Planning Law OG 153/13) that came into force on January the $1^{\text {st }}, 2014$. Understandably, this law reflects some principles defined and promoted by the EU institutions. First of all, it focusses on integrated approach to spatial planning (strategies, plans and programs) that aims at the sustainable spatial development of the national territory to be achieved through horizontal and vertical coordination. Interestingly enough, the law also stresses the need for a free 
access to spatial planning documents to guarantee the maximum level of transparency. It also awards significant importance to monitoring and evaluation of plans and strategies to be implemented in line with the EU standards. The law identifies the Spatial development strategy of the Republic of Croatia as the key instrument for territorial development and argues for integration of natural, economic, social, cultural and environmental conditions into the latter.

Whereas it is still early to see whether the new legal framework ensures spatial planning coherence and proves useful to the domestic environment, it is important to highlight that various EU principles have been shared and incorporated into the national legislation. This aspect is of significance since it results directly from a process of Europeanization through dialogic influence that allowed for some ideas and concepts defined within the EU discursive sphere to trickle down into the national spatial planning discourse.

\section{Albania}

In Albania, the local government reform is a debated topic since the fall of the communist regime. This induced a process of administrative decentralization characterized by various steps and influenced by various factors - local needs, path-dependency logics and the influence of external actors (Dhimitri et al. 2013). In fact, provided that the end of communist control and the internal process of political and economic reform surely lies among the causes behind the growing will of local administrative autonomy, the new framework of international relations, and in particular the influence of the EU also played a crucial role.

For these reasons, since 1990 the Albanian context has been characterized by several reforms, aiming at the decentralization of powers and competences (Fig. 3). However this occurred in a general atmosphere of confusion, and the administration maintained a surprisingly centralist flavour for at least a decade. The first administrative framework was composed oftwo levels: the first level comprised of 44 Bashkia (composed of cities and neighborhoods) and 313 Komuna (aggregating rural villages), whereas the second level included 36 Rrethe, in continuity with the administrative division of the previous regime. The Rrethe were then incorporated into 12 prefectures introduced in 1993 which together with a set of state agencies acted as an outpost of the various central ministries.

It is easy to imagine how, within a context of uncertain responsibilities' distribution, the decentralization of finances as well as the efficiency of the public administration was also compromised. Therefore, after signing the EU integration chapter on the local self-governments, the government introduced a new administrative reform "on the organization and functioning of local government", subsequently included in Article 13 of the Constitution of 1999 (Brahimi et al. 2013). The reform provides the country with two levels of local government, 12 regions (the 'Qarku') and 373 local units of which 65 Bashkia and 308 Komuna. While the representatives of the lower level i.e. mayors and members of municipal councils are directly elected, the board of each Qarku is composed of the representatives of Bashkia and Komunes. Furthermore, the reform keeps, as representatives of the national structure, 12 prefectures and a number of representative bodies linked to different ministries.

Although some problems characterizing the administrative subdivision of the early 1990s were solved, the identification of the role and responsibilities at the regional level in absence of selfgovernment political legitimacy remained an issue of concern (Toto 2012, 2014). This, together with the EU pre-accession requirements, stimulated a new regionalization reform that reduces the numbers of "Qarku" in favor of NUTS2 regional units with a population of over 800,000 inhabit- 
ants. This new reform that is still under discussion aims at answering the requirements of the EU integration process, calling for each candidate state to set up an administrative structure capable of efficiently intercepting and managing the pre-accession and the structural funds. Finally, the new configuration is expecting to implement a reorganization of the lower administrative level based on the principle of functional areas. Despite high expectations linked to this last reform wave, one should notice that the latter has been not producing the desired results yet. The last law approved on the matter (Law 115/2014) has indeed reduced the number of the first level local units to 61 municipalities, however have not affected the number of Qarku yet.
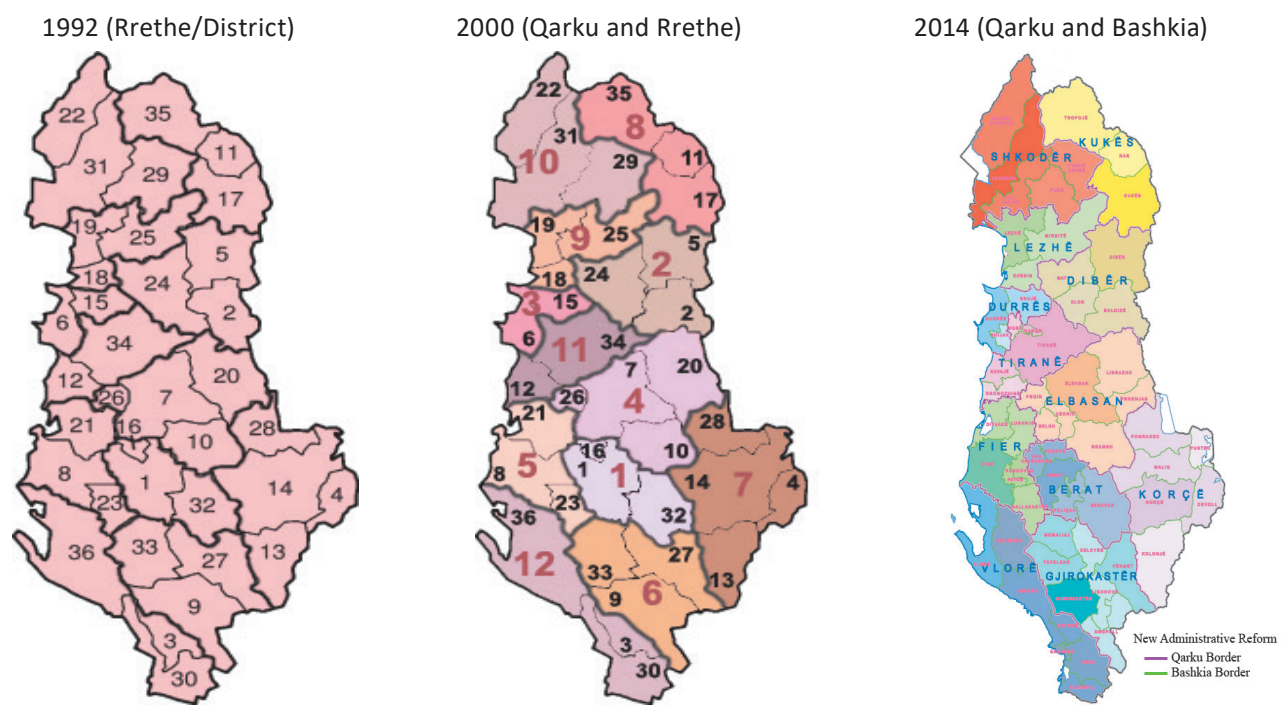

Figure 3. Territorial subdivision of Albania - 1992, 2000 and 2014

Source: http://www.kryeministria.al/en/.

In Albania, spatial planning lies under the responsibility of the Ministry of Urban Development at the central level, while at the subnational level the competences for spatial planning are shared by both Qarku and the municipalities. The first reform attempt was put in place with the promulgation of the Law 8405/1998 on Urbanism that, however, failed to produce the awaited results. In particular, the reform did not manage to solve the issues connected with the extensive informal construction processes that occurred at the country territory and failed on identifying the role that the public sector should play in defining the private and public property, in so doing avoiding to deal with the most significant challenges of the Albanian spatial development.

With the 2000s, signing of various EU agreements led to a comprehensive legal reform of the Albanian spatial planning system that concretized in the approval of a new Law on spatial planning in 2009. The law stipulates significant innovation, both at the institutional level with the introduction of national territorial planning as well as in terms of its underlying narrative, with the inclusion of concepts of clear EU inspiration. The law introduces, at different levels, diversified policy and planning tools, programs and assessment mechanisms and for the first time it requires the use of integrated inter-sectoral plans. Unlike the previous reforms, this approach has developed along with the ESDP guidelines and the EU territorial agendas. Nevertheless, the law 
has not been fully put in practice by the local administrative units yet This depends on different reasons, including lack of institutional capacity to manage the required processes, but also the path-dependent logics of local professional groups aiming at the conservation of the status quo. For these and other reasons, a new law 'for the planning and development of the territory' (Law $n r^{\circ} 107 / 2014$ ) was recently approved. While it is too early to assess the result of this reform, it is interesting to note how the latter underlines the importance to harmonize the system of national planning with the EU directives and policies, arguing in favor of a further Europeanization of Albanian spatial planning in near future.

\section{Bosnia Herzegovina}

After signing of the Dayton agreement in 1995, the State of Bosnia Herzegovina was subdivided into two entities - the Federation of Bosnia and Herzegovina (FBE that groups the majority of Bosnian Muslims and Bosnian Croatian) and the Republika of Srpska (RS that hosts the Serbian majority) - and a special unit - the arbitration territory of Brčko (DB) (Fig. 4). This agreement also divides, from an administrative point of view, the FBE into ten cantons divided in turn into several municipalities. The cantons benefit from a high degree of autonomy and are responsible for land use planning and local economic development. As far as the Republic of Srpska is concerned, on the other hand, no meso-level subdivision was implemented, and the territory is only divided into municipalities (Osmanković 2004).

Dayton Agreement

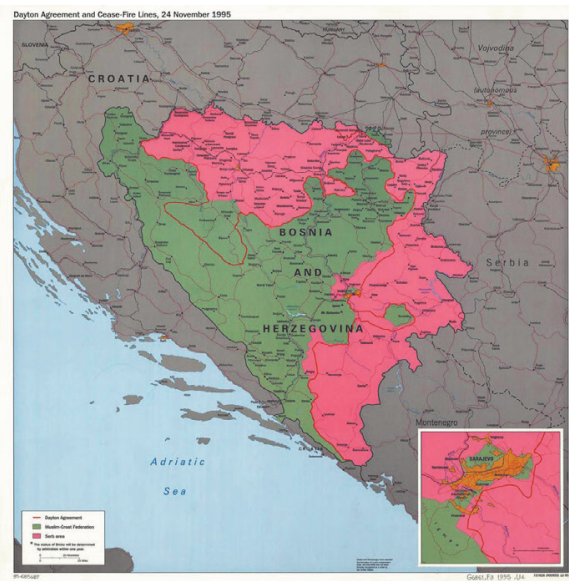

10 FBH Cantons, Brčko Distrect and Repiblic of Srpska

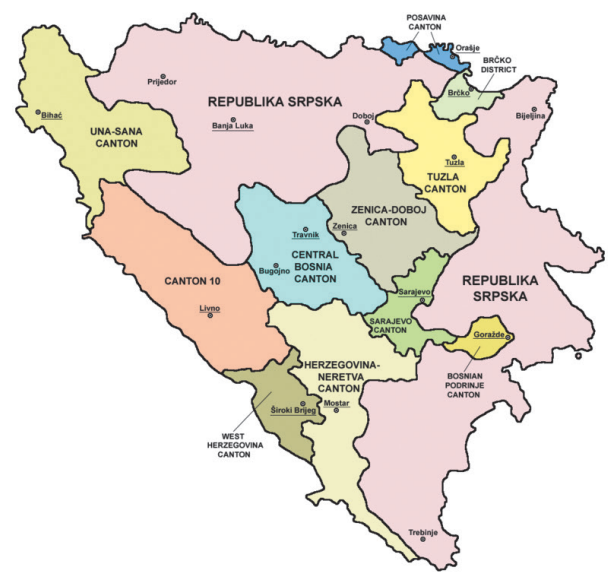

Figure 4. Territorial subdivisions of Bosnia after the Dayton Agreement Source: https://en.wikipedia.org/wiki/Cantons_of_the_Federation_of_Bosnia_and_Herzegovina.

Although the political intention behind this agreement is acceptable, the criteria of this reform are rather questionable as it prioritized ethnical and political criteria completely ignoring the economic, infrastructural and other spatial factors (Osmanković 2004). In this context, the apparent multi-level governance hides a very heterogeneous structure with the majority of powers and competences hold by the Republic of Srpska and by the FBE cantons, with the the central level that plays a very marginal role (Fagat 2012). Osmanković (2004) emphasizes the importance of the role of the international 
community actors in this process, including in the role of the High Representative ${ }^{5}$, EU and several national embassies (see also Bojičić-Dželilović 2011).

In Bosnia Herzegovina, spatial planning is an exclusive competence of the entities and Brčko District (FBE, RS, DB). In coherence with the attributed responsibilities, the entities legislate for the system of planning improvement and define the modes and conditions of land transformation and of the attribution of the building permits. Within the FBE, the Ministry of Spatial Planning is responsible for drafting and implementing spatial policies and plans at the federal level for examination and the harmonization of the plans produced by each canton and, finally, for identification of strategic development guidelines and the management of natural resources. Similarly to FBE, the Republic of Srpska has also established its Ministry of Spatial Planning, Construction and Ecology, dividing spatial planning responsibilities through different departments: spatial and urban planning, construction and environmental protection.

\section{Conclusive remarks and future research perspectives}

The proposed paper reflects upon the evolution of territorial governance and spatial planning in Croatia, Bosnia and Albania since 1989, as a consequence of two main driving forces: (i) domestic transition from a command and control economy to free market economic models (neo-liberal State restructuring), (ii) process of EU integration.

After the dissolution of the communist regimes of the 1990s, the three countries under scrutiny underwent a shift from highly centralized government and administration systems to more decentralized systems. The implemented administrative reforms have been both fluid and tumultuous, and are in some cases still pending. The evolution of the territorial administrative configuration played a pivotal role in influencing, in each State, the contextual evolution of the territorial governance and spatial planning system (Tab. 3).

Table 3. Administrative subdivision of the countries under analysis

\begin{tabular}{|c|c|c|c|c|c|}
\hline & Croatia & Albania & & Bosnia & \\
\hline \multirow{2}{*}{ First Level } & \multirow{2}{*}{ Municipalities } & \multirow{2}{*}{$\begin{array}{c}\text { Municipalities } \\
\text { (Bashkia and } \\
\text { Komuna) }\end{array}$} & Municipalities & \multirow{2}{*}{ Municipalities } & \multirow{2}{*}{ Municipalities } \\
\hline & & & Conties & & \\
\hline Second Level & Counties & Qarku & Entity of FBE & Entity of Srpska & Distrect Brcko \\
\hline
\end{tabular}

Source: author's own elaboration.

While the parallel territorial reform processes were creating a highly heterogeneous set of administrative layers, at the same time each country reformed its own spatial planning legislation in order to consider the new political, socio-economic and territorial conditions (Tab. 4).

\footnotetext{
5 The Dayton Agreement introduced the figure of the High Representative to (among other): monitor the implementation of peace settlement, co-ordinate the activities of the civilian organizations and agencies, produce periodic progress reports on the Bosnian situation, etc.
} 
Table 4. Main spatial planning legislative reforms in the countries under analysis

\begin{tabular}{|c|c|c|c|}
\hline & Croatia & Albania & Bosnia Herzegovina \\
\hline $\begin{array}{l}\text { Administrative } \\
\text { Reform }\end{array}$ & $\begin{array}{c}\text { Law on Local and Regional } \\
\text { Self-Government (1992-OG } \\
\text { 30/01, OG 153/09) }\end{array}$ & $\begin{array}{l}\text { Organization and Function of } \\
\text { Local Government } \\
\text { (N. 7572/1992-8652/2000, } \\
115 / 2014)\end{array}$ & Dayton Agreement (1995) \\
\hline $\begin{array}{c}\text { Spatial Planning } \\
\text { Reform }\end{array}$ & $\begin{array}{l}\text { Law on Spatial Planning } \\
\text { (OG 30/1994, OG 68/1998, } \\
\text { OG 50/99, OG 153/2013) }\end{array}$ & $\begin{array}{c}\text { Law on “Urbanism” } \\
\text { 7693/1993, 8405/1998, } \\
\text { 10119/2009, 107/2014 }\end{array}$ & $\begin{array}{c}\text { Spatial Planning and Land-use } \\
\text { F BE (N. 52/02, 06/2006) } \\
\text { RS (N. 84/02,. 40/13) } \\
\text { DB (N. 9/03, 15/04) }\end{array}$ \\
\hline Property Rights & $\begin{array}{l}\text { Law on Restitution and } \\
\text { Compensation of Private } \\
\text { Property } 1990 / 1996\end{array}$ & $\begin{array}{c}\text { On Rural Land } \\
(7501 / 1991) \\
\text { On Privatization of Public } \\
\text { Property }(7652 / 1992)\end{array}$ & $\begin{array}{l}\text { Property Right Law } \\
\text { RS (N. 124/08) }\end{array}$ \\
\hline
\end{tabular}

Source: authors' own elaboration.

The most notable changes include the progressive shift from government to governace reflected in new structures based on interactions among a multitude of local and regional actors, for the first time in 50 years incorporating private sector logics (Tsenkova \& Nedovic-Budic 2006). The new circumstances have promoted not only development of the new institutions but also consolidation of a 'new notion of planning' that struggled to regain its legitimacy and to adapt to the new economic, social and political mechanisms. This progressive redefinition of the role of spatial planning has occurred not without conflicts and pitfalls. In fact, during state socialism, the action was based on planning, scientific knowledge, and the party's monopoly on power and decision-making. In the new models instead, the market logics prevails, exercising innovativeness, attention to the soco-political consensus, and economic activities independent from collectively reached decisions (Tsenkova \& Nedovic-Budic 2006). Similarly this process of transformation had favored the introduction, in the long run and often only formally, of so-called "good governance" principles: legitimacy and voice (participation and consensus building); strategic direction and visions; performance (efficiency, effectiveness) accountability and transparency (Graham et al. 2003).

The reasons behind the presented institutional evolution are not obvious. Building on Vachudova (2005), this type of influence may be considered as 'passive', because it depends on each nation's predisposition to adapt its institutions according to the international requirements and pressures. In this perspective, it is possible to identify certain new institutions introduced ex-novo in all the three countries:

- Central level offices for EU Integration.

- Ministries of Integration as new key actors responsible for the relation between the domestic and the EU level.

- New, democratically elected bodies at the sub-national level, as a consequence of multiple administrative decentralization reforms.

As already argued by several authors (Pallagst 2006; Schimmelfennig \& Sedelmeier 2005; Giannakourou 2012), both transition and the EU accession processes, despite presenting several challenges, contribute to opening of several 'windows of opportunity' that, in turn, domestic actors attempted to seize to pursue their own agenda. With the support of the three channels of influence introduced above, it is possible to provide some conclusive remarks addressing the analyzed national contexts. 
First of all, the latest reform in the field of administration and spatial planning in Croatia and Albania shows the relevant role played by the so-called dialogical influence, affected by a broad set of European concepts and ideas both in terms of spatial objectives and procedures. Particular attention was paid to, among others, subsidiarity, integrated planning, vertical and horizontal integration, transparency etc., but also to territorial cohesion and sustainable development ${ }^{6}$. These aspects became constitutive elements of the domestic political agendas at the national level and therefore were able to influence the domestic spatial planning discourse, in some cases trickling down to lower levels. Furthermore, this process contributed to production of more or less evident changes in the domestic planning culture. Similarly, throughout the whole pre-accession process, the EU was able to exert a strong legislative conditionality putting pressure on the three countries to undertake processes of regionalization that, ultimately, led to more or less complex administration reforms. Last but not least, a pivotal role was played by the influence exerted by the international organizations through the set of various monetary incentive systems to back-up the undertaken reform. In this case, as a consequence of economic conditionality mechanisms, domestic actors had to choose specific reforms paths in order to secure the external economic benefits.

One should also notice the importance of domestic socio-economic structure in affecting the pace of adoption and adaptation that emerges when observing the development of the new planning legislation in each country. For instance, during the first transition phase, the Albanian socio economic situation did not allow for a sudden adaptation of the previous institutional conditions and, in particular, for introduction of a spatial planning framework pivoted around the private property, market actors and liberalization. However, the socio economic condition has quickly changed during the first part of 2000s also as a consequence of the International organization influence, (among others EU using the so-called Regional approach based on Stabilization and Association Process and Stabilization and Stabilization and Association Agreement - SAP and SAA). Inversely, throughout two years of intensive reforms (1997-1999), Croatia was able to speed up the adaptation process in terms of spatial planning tools and procedures, with the introduction of the National spatial planning strategy and program. As far as Bosnia is concerned, the Dayton Agreement, while aiming at solving various elements of conflict resulting from the outbreak of war, proved until nowto be a problematic solution for the establishment of a coherent spatial planning framework.

This first attempt to investigate the evolution of spatial planning in the Balkans through a comparative perspective highlights the need for deeper analyses. Whereas the collected evidences are unable to describe in a satisfactory way the present and future of the spatial planning patterns of change in the Western Balkan Region, they at least provide a first glimpse on the evolutionary process of spatial planning in the countries at stake and identify the potential variables that may serve as a basis for further research.

\section{References}

Adams N., Cotella G., Nunes R., 2011. Territorial Development, Cohesion and Spatial Planning: knowledge and policy development in an enlarged EU. Ashgate, Aldershot.

${ }^{6}$ All these issues has constituted as many hot topics for the European spatial development discourse since the end of the 1990s onwards. In particular, when speaking about territorial cohesion we refer to the extension of scope of the objective of social and economic cohesion to territorial issues occurred after the entrance of the Lisbon Treaty into force in 2009. 
Böhme K., Waterhout B., 2008. The Europeanization of Planning [in] A. Faludi (ed.) European Spatial Research and Policy, Cambridge: Lincoln Institute of Land Policy, pp. 225-248.

Börzel T., 2003. How the European Union Interacts with its Member States, Political Science Series no. 93.

Bojičić-Dželilović V., 2011. Decentralization and Regionalization in Bosnia-Herzegovina: Issues and Challenges, Research on South East Europe, London: London School of Economics.

Commission of the European Communities 1990. Green Paper on the Urban Environment, COM (1990) 218 final. Luxembourg: Office for Official Publication of the European Communities.

Commission of the European Communities, 1997. The EU Compendium of Spatial Planning Systems and Policies, Regional Development Studies. Luxembourg: Office for Official Publications of the European Communities.

Commission of the European Communities, 1998. Report on Community Policies and Spatial Planning: Working Document of the Commission Services. Brussels: Office for Official Publications of the European Communities.

Commission of the European Communities, 1999. European Spatial Development Perspective, Towards Balanced and Sustainable Development of the Territory of the European. Luxembourg: Office for Official Publications of the European Communities.

Commission of the European Communities, 2008. Green Paper on Territorial Cohesion. Turning territorial diversity into strength. Brussels: Office for Official Publications of the European Communities.

Cotella G,. 2009. Governance territoriale comunitaria e sistemi di pianificazione. Riflessioni sull'allargamento ad Est dell'Unione europea. PhD Thesis, Italy: Politecnico di Torino.

Cotella G., Adams N., Nunes R., 2012. Engaging in European spatial planning: a Central and Eastern European perspective on the Territorial Cohesion debate. European Planning Studies, vol. 20 (7), pp. 1-24.

Cotella G., Janin Rivolin U., 2010. Institutions, discourse and practices: towards a multidimensional understanding of EU territorial governance. Paper presented at the 24th AESOP Annual Conference, Helsinki, Finland.

Cotella G., Janin Rivolin U., 2015. Europeizzazione del governo del territorio: un modello analitico. Territorio, vol. 73, pp. 127-134.

Davies H., Edwards D., Hooper A., Punter J., 1989. Comparative study [in:] H.W.E. Davies (ed.) Planning Control in Western Europe, London, pp. 409-442.

DE Presidency, 2007, Territorial Agenda of The European Union: Towards a More Competitive and Sustainable Europe of Diverse Region. Informal Ministry Meeting on the Urban Development and Territorial Cohesion, Leipzig, Germany.

Dhimitri E., Cucllari F., Cini M., 2013. Local Government Reform and Regional Development in Albania. International Journal of Innovations in Business, pp. 277-292.

Elster J., Offe C., Preuss K., 1998. Institutional Design in Post-Communist Societies: Rebuilding the Ship at Sea, Cambridge: Cambridge University Press.

European Commission, 2015. Progress Report of Bosnia Herzegovina, Communication from the Commission to the European Parliament. SWD (2015), Commission Staff Working Document, Brussels.

Fagat A., 2012. Building Environmental Governance in Bosnia-Herzegovina: Europeanization and transnational assistance in the context of limited statehood. School of Politics and International Relation, London: University of London.

Georgiadis G., 2008. The convergence - divergence debate revisited: framing the issues. Southeast European and Black Sea Studies, Routledge. 
Getimis P., 2012. Comparing Spatial Planning Systems and Planning Cultures in Europe. The Need for a Multi-scalar Approach. Planning Practice and Research, 27(1), pp. 25-40.

Giannakourou G., 2005. Transforming spatial planning policy in Mediterranean countries: Europeanization and domestic change. European Planning Studies, 13(2), pp. 319-331.

Giannakourou G., 2012. The Europeanization of National Planning: Explaining the Causes and the Potentials of Change. Planning Practice and Research, 27(1), pp. 117-135.

Graham J., Amos B., Plumptre T., 2003. Principle for good governance in the 21st Century. Policy Brief 15, Ottawa: Intitute on Governance.

Howell K., 2002. Developing Conceptualizations of Europeanization and European Integration: Mixing Methodologies. Sheffield.

HU Presidency, 2011. Territorial Agenda of the European Union 2020 - Toward an Inclusive, Smart and Sustainable Europe of Diverse Region. Informal Ministry Meeting on the Urban Development and Territorial Cohesion, Gödöllö, Hungary.

Janin Rivolin U., 2012. Planning Systems as Istitutional Tecnologies: a Proposed Conceptualization and Implication for Comparison. Planning Practice and Research, vol. 27(1), pp. 63-85.

Janin Rivolin U., Faludi A., 2005. The hidden face of European spatial planning: Innovations in Governance. European Planning Studies, 13(2), pp. 195-215.

Kitschelt H., Mansfeldova Z., Markowski R., Toka G., 1999. Post-Communist Party Systems: Competititon, Representation, and Inter-Party Cooperation. New York: Cambridge University Press.

Knill C., Lehmkuhl D., 1999. How Europe matters. Different mechanisms of Europeanization. European Integration online Papers, vol. 3(7).

Maleković S., Puljiz J., Bartlett W., 2011. Decentralization and Regional Policy in Croatia: The impact of EU Accession and the prospect of territorial reorganization. Research on South Eastern Europe, London.

Maleković S., Puljiz J., 2009. Challenges of a New Approach to Development on the Local and Regional Level in Croatia. New Croatian Local and Regional Self-Government, Zagreb: Croatian Academy of Science and Arts.

Nadin V., Stead D., 2008. European spatial planning systems, social models and learning. DISP 172, pp. 35-47.

Newman P., Thornley A., 1996. Urban planning in Europe. London: Routledge.

Osmanković J., 2004. Regionalization and Regional Development in Bosnia and Herzegovina in the Post-War Period. Ljubljana: Institute for Economic Research.

Pallagst K., 2006. European spatial planning reloaded. Considering EU enlargement in theory and practice. European Planning Studies, vol. 14(2), pp. 253-272.

Reimer M., Getimis P., Blotevogel H., 2014. Spatial Planning Systems and Practices in Europe. A Comparative Perspective on Continuity and Change. London: Routledge.

Schimmelfennig F., Sedelmeier U., 2005. The Europeanization of Central and Eastern Europe. New York: Cornell University Press.

Sedelmeier U., 2006. Europeanisation in new member and candidate states. Living Reviews in European Governance, vol. 6(1), pp. 1-52.

Stead D., Nadin V., 2009. Planning cultures between models of society and planning systems [in:] J. Knieling F. Othengrafen (eds.), Planning Cultures in Europe: Decoding Cultural Phenomena. Urban and Regional Planning, Ashgate.

Stead D., Cotella G., 2011. Differential Europe: Domestic actors and their role in shaping spatial planning systems. disP-The Planning Review, vol. 47(186), pp. 13-21. 
Tendler J., 2000. Why are social funds so popular? [in:] Y. Shahid et al. (eds.) Local Dynamics in the Era of Globalization. Oxford: University Press, pp. 114-129.

Toto R., 2012. Rajonalizimi i Shqipërisë në debat - fuqizimi i decentralizimit dhe evoluimi drejt zhvillimit rajonal 2. Linjat e debatit për zhvillim rajonal apo rajonalizim në Shqipëri, pp. 317-344.

Toto R., 2014. Shqiperia-Riforma Territoriale Perkundrejet Rajonalizimit, pertej decentralizimit, Ministria e Integrimit Europian, Tirane.

Tsenkova S., Nedovic-Budic Z., 2006. The urban Mosaic of Post-Socialist Europe: Space, Institutions and Policy. Physica-Verlag, A Springer Company.

Vachudova A., 2005. Europe Undivided: Democracy, Leverage and Integration After Communism. OuP Oxford.

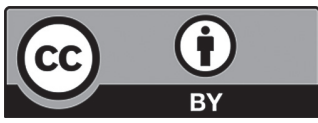


http://rcin.org.pl 